\title{
The Effect of Using Ausubel's Assimilation Theory and the Metacognitive Strategy (K.W.L) in Teaching \\ Probabilities and Statistics Unit for First Grade Middle School Students' Achievement and Mathematical Communication
}

\author{
Abdul-Rehman Al Tamimi, PhD \\ University of Hail, Hail, Saudi Arabia
}

\begin{abstract}
The study aimed to investigate the effect of using Ausubel's assimilation theory and the metacognitive strategy (K.W.L) in teaching statistics and probability unit for students of second grade - middle school students' achievement and mathematical communication. The study sample consisted of 168 grade - middle school students in Hail. They were randomly divided into two experimental groups; the first $(N=56)$ students and the second $(N=56)$, and a control group $(N=56)$. The first experimental group was studied using Ausubel's model; the second experimental group was studied using the metacognitive strategy (K.W.L); and the control group was studied using the conventional method. The research tools used in this study is an achievement test and scale for mathematical communication. The results showed that there were significant differences in achievement for the first and the second experimental group compared to the control group. Hence, this demonstrates the effectiveness of these two methods in teaching. The results showed statistically significant differences in mathematical communication due to the teaching methods. In addition, the second experimental group outperformed the first experimental group and the control group. The results also showed a statistically significant difference between pre-administration and the postadministration in favor of the post-administration for the three research groups. Further recommendations were suggested for future research.
\end{abstract}

Keywords: Ausubel's assimilation, (K.W.L), mathematical communication

\section{Introduction}

Today's world is witnessing rapid changes and massive development in all areas in general and in the fields of science and technology in particular. 
This development coincided with a shift in scientific research such that the outlook of the educational process was changed. Therefore, it is no longer the result of external factors such as teacher, curriculum, and learning environment only. However, there are internal factors affecting the learning process; such as the learner's ability to think. Much concern was given to theories of learning which focuses on teaching students on how to think.

Curricula should encourage students to react positively, suggest, and discuss new ideas. This basically is an intellectual process that needs to be developed continuously. Thus, this requires efforts, constant exercise and directed intended practice, and requires one to give the best result in developing new plans to change reality (To'eima et al., 2011, p.439).

Mathematics, as a basic science, is concerned with the studying of intellectual topics such as numbers, algebraic symbols, and among them abstract topics such as shapes and the relationships between them or between their parts (Al-Amin, 2001, 3).

It is worthy to mention that the most important goals of mathematics education is knowledge and the development of mathematical skills, which include concepts and skills in solving mathematical problems (Bayat \& Tarmizi, 2010, 403)

The last decade in the $20^{\text {th }}$ century has witnessed a widespread movement which brought about radical changes in the teaching mathematics curriculum. Much concern has been given to cognitive structures in teaching topics by the beginning of the sixties of the previous century. Ausubel's assimilation theory stated that learning occurs through the assimilation of new concepts into existing concept frameworks held by the learner. If the targeted concept is logically connected to the learners' structure of knowledge, and if the structure of knowledge is organized clearly, then learning the concept meaningfully will be easier in the light of these two conditions (logical connection and clarity of cognitive organization) (Ausubel,1998).

The Ministry of Education in Saudi Arabia emphasized on curriculum development to keep pace with the developed countries and keep pace with the era of progress and prosperity. This is evident through the project of educational development company (2015), which was established in 2008. However, it includes many educational projects which work on the development of public education. This includes a program to enhance $21^{\text {st }}$ century skills, life, and labor market program. The program aims to improve the preparation of students to qualify them for higher education and the transition from school to professional life. This is achieved by providing educational and training services in an interactive framework. Also, it supports the growth of their personality and their orientation, enhances the concept of good citizenship and social responsibility, and it prepare them academically 
and professionally in accordance with the labor market requirements in the twentieth century.

\section{The Research Problem}

The current research problem is identified in finding out effective teaching methods to stimulate students' self-learning. This is done by taking into account individual differences among them, and expanding the horizons of the learner's knowledge. However, it can be seen from the previous preview that both Ausubel's assimilation strategy and the metacognitive strategy (K.W.L) can be used to improve the learning process. Due to the importance of the comparison between these two strategies, the research will provide information that can be useful to decision-makers. This is with regards to the effectiveness of these methods and the interpretation of student achievement and mathematical communication through determining the effect of teaching method on achievement and mathematical communication. As a result, the current research seeks to use strategies (Ausubel's assimilation strategy and the metacognitive strategy (K.W.L)) in teaching mathematics. However, this is with the aim of improving the level of achievement and mathematical communication.

Accordingly, the research focuses on the main question "What is the effect of using Ausubel's assimilation strategy and the metacognitive strategy (K.W.L) on mathematics achievement and the development of mathematical communication for the first-grade middle school students?"

\section{The Research Problem}

\section{The research attempts to answer the following question:}

"What is the effect of using Ausubel's assimilation strategy and the metacognitive strategy (K.W.L) on mathematics achievement and the development of mathematical communication for the first-grade middle school students?"

The two sub-questions are as follows:

1. What is the effect of using Ausubel's assimilation strategy and the metacognitive strategy (K.W.L) on mathematics achievement for the firstgrade middle school students?

2. What is the effect of using Ausubel's assimilation strategy and the metacognitive strategy (K.W.L) on developing mathematical communication for the first-grade middle school students?

\section{Research Hypotheses}

In the light of related literature, the following hypotheses are formulated to be tested: 
1. There is no significant difference at the 0.05 level between the mean score of the experimental group students and that of the control group achievement due to teaching strategy.

2. There is no significant difference at the 0.05 level between the mean score of the experimental group students and those of the control group on mathematical communication scale due to teaching strategy.

3. There is no significant difference at the 0.05 level among the mean score of the experimental group students and those of the control group (achievement and mathematical communication) due to teaching strategy.

\section{Limitations of the Research}

The results of this research can be generated in the light of the following limitations:

1. In developing achievement and mathematical communication, the research is limited to using Ausubel's assimilation strategy and the metacognitive strategy (K.W.L).

2. The research is limited to first-grade middle school participants in a middle school in Hail City - Kingdom of Saudi Arabia.

3. The research is limited to one unit (Probabilities and Statistics).

4. The research time limitation is the second semester $(2015 / 2016)$.

\section{Terminology}

Ausubel's Assimulation: A cognitive learning theory holds that people learn best when they can link, or assimilate, new information with previous knowledge. It involves three stages: Planning, implementation, and evaluation.

K.W.L Strategy: K.W.L is a concept structure-based strategy which depends on constructive theory. It hypnotizes that, to build a concept, a learner interacts with new and old information through three stages;

What I Know about a topic? /What I Want to know about the topic? What I have learned?

However, it is operationally defined as: Students begin by brainstorming everything they Know about a topic. This information is recorded in the $\mathrm{K}$ column of a K-W-L chart. Students then generate a list of questions about what they Want to Know about the topic. Also, students answer the questions which are in the $\mathrm{W}$ column. This new information is what they have Learned.

\section{Mathematical Communication}

NCTM (1989) defined Mathematical communication as a learner's ability to use Mathematical vocabulary, symbols, and the structure of the 
language to express ideas and relationships, understand it, and then explain it to others.

Operationally, it is defined as the student's ability to use the language of mathematics through symbols, representations, and shapes in the expression of mathematical ideas and data processing.

\section{Theoretical Framework}

The theoretical framework includes the following themes: K. W. L. Strategy

KWL strategy is considered as one of the metacognition strategies, which is related to Dettrich Graham in 1980. Here, the Donaa Ogle in 1986 was developed and put into the final form which is known now. Then, the strategy evolved later on the hands of both Eileen Shaw Blaskwoski, and it took many forms (AttiaSaleh, 2008, 64). This study will discuss KWL strategy given the importance of its implementation in the classroom.

Consequently, there are many definitions of KWL. The most important definition is that they are "strategy used by teachers to stimulate students' thinking on the topic of the lesson before the new learning begins" (kopp, 2010, 10).

Also, it is defined as one of the constructivist learning strategies in which a student records all of his information earlier on the topic. After then, he or she decides and reports what is needed in the light of what information the teacher delivers. Furthermore, he or she records what they actually learned and they also report the most important implementation of what they learned. Therefore, this can be done in the form of an individual or in groups organized by the teacher as the situation required (Attia Saleh, 2009, 59).

By exploring the previous definitions and the operational definition of K.W.L strategy, which the researcher suggested, the following conclusion can be drawn:

- K.W.L is considered as one of the constructivist learning strategies as well as the strategies and metacognition one.

- This strategy is based on the students' recall for their prior knowledge.

- It includes a set of steps; defining prior knowledge, knowledge to be learned, and learned knowledge.

- This strategy represents a good way to attract the attention of students and to depart from the normal daily routine of the traditional classes.

\section{Steps of K.W.L Strategy}

According to K.W.L strategy, a lesson follows the following steps:

1. Determining the topic to be studied and planning K.W.L strategy strategic schedule. 
2. Identifying and recalling the prior knowledge of the learner and related topics, and writing them in the column " $\mathrm{K}$ " as the basics of learning.

3. The teacher asked the students what they want to know about the topic, and they recorded the questions on the second column "W."

4. Reading the topic with the help of a teacher and guidance for the students or through a textbook or worksheets. It can also present the topic with the use of a L-C-D. Then, the information can be recorded in the column "L." This is done such that the information can answer to the questions raised by the students in the next column.

5. Discussing the information recorded by the students, and encouraging them to search for answers to the questions they attained in the column "W" when they cannot get the answers.

It is worthy to mention that the order of the steps is of great importance for the success of the strategy to be effective in the learning process. However, various steps should be implemented based on the obligation of both the teacher and the student (Jennifer, 2006, 2- 4).

\section{Advantages of K.W.L Strategy}

This strategy carries many advantages (Abraham, 2005, 125) (Bahloul, 2004, 185), including:

- Supporting the idea of the focus on student-centered learning rather than the teacher-centered learning.

- Helping the teacher to achieve advanced steps to enhance classroom learning environment.

- The teacher can enable students to tackle any topic irrespective of the degree of difficulty through reactivating their prior knowledge and raising their curiosity.

- Students can report and command their own learning. Hence, the role of the teacher is to attribute their success in their self-learning based on their exerted efforts.

-It can be used at all stages of education and learning materials.

\section{The Importance of using K.W.L Strategy}

This strategy is of a great importance in the field of education (Salem, 2007, 40-41) for the following reasons:

- Activating prior knowledge stored in long-term memory.

- Increasing questioning skill and self-questioning and activating selfmonitoring.

- The coherence and cohesion of the cognitive framework of learners through the re-organization of the knowledge structure.

- Organizing thinking, its operations, and sequencing. 

information.

- Assisting in planning, data collection, and in predicting sources of

- Contributes to selective understanding because it represents an invitation to examination and promotes the search of related events with regards to new learning.

- Contributes in creating opportunities for creation and innovative thinking. This kind of thinking relies on activating prior knowledge. Also, it tries to reformulate it in a new form.

\section{Teacher and Learner's Roles in K.W.L Strategy} follows:

Consequently, the main roles of both teachers and students are as

The teacher's roles include: planning for the goals of the lesson, discovering students' prior knowledge, controlling classroom conditions and discussion groups, guiding and organizing students' knowledge, suggesting questions that work to raise the students' thinking, correcting students' mistakes, and evaluating students' performance. The student's roles are: read, watch or listen to the topic and recalls ideas, ask questions that meet the cognitive needs, practice independent thinking and classify ideas included in the topic, training students practice of collaborative thinking, discussing and interviewing in the classroom, and correcting what was previously stored in prior knowledge (Zahrani, 2011, 24).

Furthermore, the researcher believes that the teacher and student's roles complete each other. It is evident that, during the procedures in the classroom, a teacher has to identify and organize prior knowledge, lead alternative developments by comparing what has been learned to what was previously thought, promote student's good ideas, provide feedback and enhance positive values such as cooperation between the members of the group and the competition between the groups in the presentation of the results of their learning. On the other hand, a student has to present prior knowledge about the topic, recorded in the first column, where the teacher organizes such knowledge following the identification of the questions he/she wants to answer. Then, he/she writes them in the second column, and codify what has been learnt after studying the topic. After then, he/she records them in the third column. Finally, it compares what has been learned to what was previously taught, and it corrects any wrong concepts and ideas.

\section{Ausubel's Strategy}

Ausubel's strategy is based on theories that focused on the organization of the content. This is based on the assumption that the most important factor influencing learning is the amount of clarity and organization of current 
knowledge. However, the current knowledge which is made available to the learner is what he calls cognitive structure.

Meaningful Learning is considered as the essence of Ausubel's strategy. Thus, it is intended to: link the new information prior knowledge in the cognitive structure of the learner. This is such that the new information will be of the same quality with regards to the cognitive structure or similar (Kilada, 2008, 307).

Ausubel defined cognitive structure as "all the knowledge we have acquired as well as the relationships among the facts, concepts, and principles that makes up that knowledge" (Salama, 2002, 329).

To achieve learning based on meaningful learning, Ausubel's suggested two principles to organize the curriculum. The first one is called "Differentiation Progressive". This implies the organizing of the curriculum so as to first provide a more general and inclusive ideas and concepts, and then branch steadily in detail and specialization. The second principle is known as "integrative Reconciliation". This refers to the integration and compatibility of new information from the content of academic discipline with the previous information learned in the same discipline.

Ausubel classified learning into four categories based on two dimensions:

The first dimension has to do with methods and techniques through which educational materials are provided to students. Thus, they obtain knowledge in two methods: reception method, which is providing information to the learner in its final form as in the meetings or lectures. It is also known as reception learning. The other method is the exploration method, in which content is not given to the learner in the final form. Rather, the learner is asked to discover information partially or completely. Also, the teacher tries, in a limited way, to incorporate information or associate it with learner's cognitive structure in the first place.

The second dimension concerns the means used by the student to remember the educated material or linked it to cognitive structure possessed. However, it is divided into two types: Rote learning where the students memorizes educational materials and hold it. This is done without creating any association or relationship between them, and between the existing cognitive structure. Thus, the retention of educational material is done automatically. On the other hand, meaningful learning is connecting the new educational material in organized and non-random manner as owned by the learner from previous information that can be remembered or called (Lawton, 1999, P 85). Consequently, Ausubel selected four main types of classroom learning which are: 
Rote Reception Learning: The learning materials take the final form and the learner remembers them all without dealing with information in his/her prior knowledge.

Meaningful Reception Learning: In this type of learning, the learner takes organized learning material in its final form and links it to learning material in his/her prior knowledge existing in the cognitive structure. Basically, there are two reasons behind the positive relationship between learning and retention. The first reason is that the more educated, experienced and organized the learner is, the quicker the learning occurs. The second reason is that learning and remembering are supposed to occur together. Thus, any separation between them is an artificial work.

Discovery Rote Learning: This learning is based on rehearsal and memorization. Here, the learner reaches the method to solve the problem and the information which is used in the solution independently in order to retain information in the memory. This is done without linking them with prior knowledge in the cognitive structure.

Meaningful Discovery Learning: This type of learning helps the learner to reach the solution of the problem or to retain the learning material for this task independently based on the information and knowledge presented. Hence, knowledge is an addition to the learning situation. Information and knowledge are connected to cognitive structure (Al-Zubaidi, 2011, 416418).

Through the four learning types, it is obvious that the idea of linking the new information and the cognitive structure of the learner distinguishes Ausubel's meaningful learning. Thus, this is one of the most important conditions for its occurrence.

\section{Advantages of Ausubel's Strategy}

1. It provides the recipient with general idea for a few minutes in debating the subject matter that makes the recipient more willing to distinguish between fundamentals and details in cognitive structure.

2. It promotes student's discrimination ability, and builds a bridge between what he/she uses, his/her cognitive structure, and the learning situation.

3. It makes the learner able to harmoniously integrate at a level of abstraction and generalization, and his/her intellectual ability is considered to be higher than the content in textbooks.

\section{Mathematical Communication}

The mathematics education reformat stressed the importance of mathematical communication as an essential component in the learning and teaching of mathematics, the importance of working to provide opportunities 
for students to interact with each other during the performance of mathematical situations, sharing what is on the minds of the ideas and opinions of mathematical proposals, work to help students find a link between mathematics and the language they speak, and the use of the language in their daily lives. However, this comes through the translation of life situations to mathematical language through the use of symbols, variables, and modeling (Anderson \& Little, 2004; Cook \& Buchholz, 2005).

Mathematical communication does not only refer to the student's ability to use the mathematical language to express what wanders in his/her mind and feels the ideas, but it also refers to the student's ability to think, reason, justify, and communicate to share ideas and exchange views and proposal between the teacher and students or between students themselves. In addition, it also considers whether it is all about the mathematics or about life situations addressed by mathematical activities (Badawi, 2003). Subsequently, mathematical communication in the classroom may take different forms of languages which may be in written or verbal (Badawi, 2004; Cai \& Kenney, 2000).

Mathematical communication refers to an individual's ability to use words and symbols and structure of mathematics to express mathematical ideas and relationships in verbal or non-verbal form. National Council of Teachers of Mathematics in the United States (NCTM, 1989) indicated that what a learner acquires in mathematics contribute to the enrichment of the linguistic proficiency and impart a greater ability to mathematically communicate through the use of numbers and shapes. As a result, there is a mathematical communication among the most important criteria for learning mathematics at the present time. However, this confirms what was concluded in a large body of educational literature on teaching mathematics.

Subsequently, it is known as one of the mathematical ability that enables the learner to use mathematics when facing mathematical oral or written discussions with others. In addition, they are well able to employ the use of words, symbols, and structure of mathematics in the expression of ideas and relationships and to clearly understand them (Al-Nazeer \& Khashan, 2012, 3).

The National Council of Teachers of Mathematics in the United States (NCTM, 1989) classified mathematical communication into four levels:

1. Organize mathematical thinking through communication.

2. Communicate their mathematical thinking coherently and clearly to peers and others.

3. Analyze and evaluate the mathematical thinking and strategies of others.

4. Use the language of mathematics to express ideas precisely. 
Badawi (2003) added that mathematical communication in the classroom takes many different forms of the language. This may be oral or written and formal or informal which occurs between students and the teacher or the student and another. Therefore, this includes sports communication in two important aspects, namely:

1. Communicate with the language of mathematics about mathematics itself.

2. Communicate with the language of mathematics about other educational materials or life situations.

The mathematical communication is considered to be an essential goal of Mathematics education. However, the National Council of Teachers of Mathematics in the United States (NCTM, 1989) classified it into listening, reading, speaking, writing, and representation.

\section{Related Literature}

\section{Studies Related to KWL Strategy}

Yimer (2004) aimed to study the relationship of metacognitive strategies and academic achievement among middle school students. The researcher adopted KWL strategy and was introduced by his lessons to the experimental group (38 students). Thus, this was performed using that strategy while the control group (35 students) was studied using the conventional approach. The results indicate that the achievement of the experimental group students was higher than the achievement of the control group students. Also, the poor performance of students in mathematical problem solving is not due to lack of adequate mathematical knowledge, but due to the lack of students' ability to carry out regulation and monitoring learning.

Barakati (2008) investigated the effect of teaching via the employment of strategies of multi-intelligence, Six -hat, and K.W.L. in knowledge attainment and mathematical association among female students of the Third Intermediate Class at the schools in Makkah Al-Mukarramah. In her study, she studied the unit of geometrical solids. The researcher prepared a teacher's guide and an achievement test as well as a test to measure the two skills of mathematical association and mathematical communication. The study sample comprised (95) female students, who were randomly distributed among four groups; the first three were experimental group and the fourth is the control group. The first experimental group was taught according to the strategy of multi-intelligence; the second was taught according to the six -hat strategy; and the third was taught according to K.W.L. strategy. On the other hand, the control group was taught according to the conventional strategy. The results showed higher achievement for the two groups of multiple intelligences and KWL. In addition, it is also compared to the control group based on the level of evaluation. 
Tok (2013) examined the effects of the Know-Want-Learn (KWL) strategy on 6th graders' mathematics achievement, metacognitive skills, and mathematics anxiety. A pretest-post test control group quasi-experimental design was used in the study. The sample of the study was composed of 55 6th graders who were attending public elementary schools. Subsequently, the data was collected by administering the "Math Achievement Test", "Metacognition Inventory", and the "Math Anxiety Scale". The "KWL strategy" was used in teaching mathematics to the study group, whereas the control group was taught using the "conventional method". The results of the study showed that employing the "KWL strategy" in 6th grade mathematics can be effective in increasing achievement and metacognition. Nevertheless, it was not efficient than the conventional method regarding the reduction of anxiety.

Siribunnam, and Tayraukham (2009) investigated the effect of learning cycle, KWL learning method, and conventional approach on analytical thinking. The sample consisted of 154 students in the fifth grade Mahasarakham Province in Thailand. The sample was divided into two experimental groups who learned using the 7-E learning cycle and KWL learning activities. Furthermore, it was also divided into one control group who learned using the conventional approach. The research instruments were: (1) 12 lesson plans for organization of 7-E learning cycle, 12 lesson plans for organization of KWL learning method, and 12 lesson plans for the organization of the conventional approach; (2) A 30-item analytical thinking test; (3) A 40-item achievement test of science learning achievement; and (4) A 20-item of attitudes toward chemistry learning. However, the results of the study revealed that the students who learned using the 7-E learning cycle, KWL learning method, and the conventional approach differently showed analytical thinking, science learning achievement, and attitudes toward chemistry learning at the 0.05 level of significance. The students who learned using the 7-E learning cycle showed more science learning achievement than students who learned using KWL learning method. However, the result indicated that analytical thinking, science learning achievement, and attitudes toward chemistry learning is higher than in students who learned using the conventional approach. In addition, the students who learned using KWL learning method showed higher analytical thinking than students who learned using the conventional approach.

The study of Aram (2012) is aimed at investigating the effect of using KWL strategy in acquiring the concepts and critical thinking skills in science among students of the seventh grade. It makes use of content analysis and experimental method. The study sample consisted of 97 female students from the seventh grade in "Eilabun" basic common school in the city of Khan Younis. Thus, the sample was divided into two groups; experimental group (48 students) and control group (49 students). The results showed statistically 
significant differences between the mean score of the two groups (experimental and the control group) concepts. This is with regards to scientific and critical thinking skills in a test in favor of the experimental group.

\section{Studies Related to Ausubel's Strategy}

Macdragh (2001) examined the effect of prior knowledge and advance organizer in developing some science concepts. The sample consisted of 99 students who were divided into three groups according to their levels (highlevel, and intermediate grades, low grades). Then, each group was divided into the experimental group which studied the unit rocks using advance organizers. Also, a control group studied the same unit without the use of advanced organizations, the differential IQ test, and the achievement test which were administered. Also, the experimental group performed better than the control group. The study revealed that there was a correlation between differential IQ test, abstract thinking ability and collection, and achievement. Prior knowledge had a significant impact on students' achievement of concepts Science

The study of Abdali (2006) aimed to investigate the effect of using Gagne and Ausubel's educational models based on the achievement of the first grade secondary students in biology and their learning retention. The researcher selected a sample of 58 first grade secondary school students. They were divided into two groups; one experimental group and one control group. Then, the researcher prepared educational material according to the models used in the study, and based on the construction of a multiple choice achievement test. The study revealed that there were no statistically significant differences between mean scores of Gagne group students who studied according to Gagne model and the mean scores of Ausuble group students who studied according to Ausuble model in the overall achievement, and at the level of students: high, intermediate, and low for both groups, as well as in the achievement levels (remembering, understanding and application).

Al-Zubaidi's (2011) study aimed at investigating the retention of learned material in the light of Ausubel theory. The study concluded that the retention of learned material which is a fundamental goal of the process of education should be paid attention to. Also, the advance organizers are practical key to the sequence of steps for effective teaching process. The feedback is the umbilical cord to the vitality learned material. The efficient and logical connection between the learning environment and the new material is a security-rule for life learning situation. The study shed light on the importance of focusing on the background of the learner which is the premise for the proper process to retain learned material. It is also the way to lengthen the retention of the learning material. 
Al-Khathlan (2012) aimed to design a unit in accordance with Ausubel and Brunner theories to develop computer curriculum assigned for secondary school students and the study of their effectiveness. The sample consisted of 60 students from the high school students. These students were divided into two groups; one experimental and the other control. Also, in the study, it was found that there was a positive effect of the unit prepared according to Ausubel and Brunner theories based on the improvement and development of attitude towards computer.

\section{Studies Related to Mathematical Communication}

Orabi (2004) aimed to measure the effectiveness of the use of alternative evaluation methods to improve the achievement of basic fourthgrade students, improve their ability to communicate mathematically, reduce mathematics anxiety, and determine the relationship between the variables of the study. The results showed the effectiveness of the alternative evaluation on increasing verbal mathematical communication as a whole and its subskills. Also, it was found that there was a negative relationship between mathematical communication and test anxiety.

The study of Hashash (2004) examined how to achieve the criteria of mathematical representation and communication for higher primary school students in Jordan. This was done in the light of the principles and standards of NCTM. The results of the analysis in the field of communication aimed to discover inaccuracies in the oral verbal expression for mathematical and geometric concepts and generalizations, and the confusion among them. The most common pattern for participation was lifting hands up. It also involves the movement of the head to the bottom as an expression of understanding, which is a non-verbal expression. Students read algebraic expressions, roots, variants, angles and shapes improperly. This was done with inaccurate evaluation of mathematical ideas, the domination of teaching procedures pattern in the lessons of algebra, and the style of teaching questioning pattern in geometry.

Metwally (2006) aimed to determine the effectiveness of using indirect proofing approaches in developing mathematical proof skills, reducing proof anxiety, and improving communication skills for mathematics studentteacher. The study sample consisted of third year students of Mathematics department at the College of Education, Sur- Sultanate of Oman. 57 students were divided into two groups; the experimental group (30 students) and the control group (27) students. The study results indicated the presence of the effectiveness of using indirect proofing approaches in developing mathematical communication skills. Also, the results of the study showed the existence of a positive relationship between improving mathematical 
communication skills, all the low level of the students' anxiety of the mathematical proof, and the development of mathematical proof skills.

- The study of Al-Nazeer \& Khashan (2012) aimed to study the effect of a training program based on the standards of mathematical communication on the achievement and attitudes towards mathematics at the preparatory year students at King Saud University for the syllabus of Calculus. The study was conducted on a sample which consists of 68 students of the year preparations at King Saud University for a period of 6 weeks. The sample was divided into experimental and control group, and two tools were administered to the sample: the test and measuring scale of attitude towards mathematics. However, the study found that there are statistically significant differences in both academic achievement and the attitude towards mathematics in favor of the experimental group.

\section{Comment on Related Studies}

- Studies discussed varied aspects which dealt with the effect of using advanced organizers in teaching in relation to one or more of the following: academic achievement, acquiring intellectual or psychomotor skills, learning retention, improve motivation, scientific attitudes, and facilitating consequent learning.

-There was an agreement among the results of most of the studies based on the importance and effectiveness of metacognitive strategies in general, K.W.L strategy, and Ausubel's model in particular in promoting the academic achievement of the students. In addition, studies agreed on the strategic use of the experimental method for comparison with the conventional method.

- International and regional studies emphasized using the empirical research in the development of the educational process because it gives effective results in the educational field.

- The present study differs from previous studies in that it uses K.W.L strategy and Ausubel's model together to increase academic achievement and mathematical communication for first grade - middle school students.

-Previous studies have confirmed the importance of a standard mathematical communication recommended by NCTM for its utility in developing students' skills of communication.

-The current study took advantage of previous studies in the writing of the theoretical framework and the interpretation of results.

\section{Methodology and Procedures Participants}

The study sample consisted of 168 second grade middle school students at three middle schools in Hail during the second semester of the 
academic year (1435/1436 AH). The schools were selected randomly. Furthermore, the participants were selected randomly and distributed on the experimental study groups and the control group randomly. Table 1 shows the distribution of members of the study on the experimental groups and the control according to the teaching methods.

Table 1. Sample distribution according to schools and the teaching methods

\begin{tabular}{|c|c|c|c|c|}
\hline Groups & $\begin{array}{c}\text { Thabet Bin Quis } \\
\text { Schools }\end{array}$ & $\begin{array}{c}\text { Al-Shora } \\
\text { Schools }\end{array}$ & $\begin{array}{c}\text { Al-Madina Al- } \\
\text { Monawara school }\end{array}$ & Total \\
\hline Control & 19 & 17 & 19 & 56 \\
\hline Experimental (1) & 20 & 19 & 18 & 56 \\
\hline Experimental (2) & 19 & 18 & 19 & 56 \\
\hline Total & 58 & 54 & 56 & 168 \\
\hline
\end{tabular}

\section{Study Tools}

\section{Achievement Test}

The initial testing version consisted of (10) questions made up of (20) multiple choice items. It aimed at measuring students concepts of statistics and possibilities assigned in the course. Test validity was confirmed through reviewing done by referees. Extreme-groups comparison validity was calculated on a sample of 30 students from the research population and from outside the original sample. The difference between upper quartile (8) students and lower quartile (8) students is shown according to following table.

Table 2. The significance of differences between upper quartile and lower quartile for cognitive achievement

\begin{tabular}{|c|c|c|c|c|c|c|}
\hline Variables & \multicolumn{2}{|c|}{ lower quartile } & \multicolumn{2}{c|}{ upper quartile } & $\mathrm{t}$ & significance \\
\hline cognitive achievement & 9.3750 & .91613 & 12.3750 & .51755 & 8.064 & .0000 \\
\hline
\end{tabular}

Table (2) shows that there are statistically significant differences at the 0.05 level between the upper quartile and lower quartile in favor of upper quartile in cognitive achievement. This means the test has the ability to distinguish between high-level groups and low-level groups indicating the test validity. Test reliability was confirmed by administering the test to a sample of 30 students from the research community and from outside the original sample. Then, it repeats the administration on the same participants after 10 days in the same circumstances. The following table illustrates this.

Table 3. Correlation between First and second administration of cognitive achievement test

\begin{tabular}{|c|c|c|c|c|c|c|}
\hline \multirow[b]{2}{*}{ Variable } & \multicolumn{2}{|c|}{ Pre-test } & \multicolumn{2}{|c|}{ Post-test } & \multirow[b]{2}{*}{$\begin{array}{c}\text { correlatio } \\
\mathrm{n}\end{array}$} & \multirow[b]{2}{*}{$\begin{array}{c}\text { significanc } \\
\mathrm{e}\end{array}$} \\
\hline & $\begin{array}{c}\text { Mea } \\
n\end{array}$ & $\begin{array}{c}\text { Standard } \\
\text { deviatio } \\
n\end{array}$ & $\begin{array}{c}\text { Mea } \\
\mathrm{n}\end{array}$ & $\begin{array}{c}\text { Standard } \\
\text { deviatio } \\
n\end{array}$ & & \\
\hline $\begin{array}{c}\text { Cognitive } \\
\text { achievement }\end{array}$ & $\begin{array}{c}10.9 \\
0\end{array}$ & 1.27 & $\begin{array}{c}11.2 \\
0\end{array}$ & 1.32 & 0.87 & .000 \\
\hline
\end{tabular}


Table (3) shows that there is a statistically significant correlation at the 0.05 level between the pretest and the post-test scores of cognitive achievement and mathematical communication variables. This, however, indicates the reliability of the test. After confirming the validity and reliability of the test, it was put in its final form consisting of six questions and a total of 10 items and all of them are multiple choice.

\section{Mathematical Communication Scale}

The researcher prepared a mathematical communication scale based on previous studies. In the initial form, the scale consisted of 14 items covering 4 dimensions. The scale was presented to a juries committee - specialists using the method of teaching and psychology. Also, the scale was modified according to their suggestions. Extreme-groups comparison validity was calculated on a sample of 30 students from the research population and from outside the original sample. The difference between upper quartile (8) students and lower quartile (8) students is shown according to following table.

Table 4. The significance differences between upper quartile and lower quartile for mathematical communication

\begin{tabular}{|c|c|c|c|c|c|c|}
\hline Variables & \multicolumn{2}{|c|}{ lower quartile } & \multicolumn{2}{|c|}{ upper quartile } & $\mathrm{T}$ & $\begin{array}{c}\text { significanc } \\
\mathrm{e}\end{array}$ \\
\hline Mathematical & 6.250 & 1.1649 & 8.625 & .5175 & 5.27 & .0000 \\
communication & 0 & 6 & 0 & 5 & 0 &. \\
\hline
\end{tabular}

Table (2) shows that there are statistically significant differences at the 0.05 level between the upper quartile and lower quartile in favor of upper quartile in mathematical communication. This means the scale has the ability to distinguish between high-level groups and low-level groups indicating the test validity. The reliability was confirmed by administering the scale to a sample of 30 students from the research community and from outside the original sample. After then, it repeats the administration on the same participants after 10 days in the same circumstances. The following table illustrates this.

Table 5. Correlation between First and second administration of mathematical communication scale

\begin{tabular}{|c|c|c|c|c|c|c|}
\hline \multirow[b]{2}{*}{ Variable } & \multicolumn{2}{|c|}{$\begin{array}{c}\text { First } \\
\text { administration }\end{array}$} & \multicolumn{2}{|c|}{$\begin{array}{c}\text { Second } \\
\text { administration } \\
\end{array}$} & \multirow[b]{2}{*}{$\begin{array}{c}\text { correlati } \\
\text { on }\end{array}$} & \multirow[b]{2}{*}{$\begin{array}{c}\text { significan } \\
\text { ce }\end{array}$} \\
\hline & Mean & $\begin{array}{c}\text { Standar } \\
\mathrm{d} \\
\text { deviatio } \\
\mathrm{n}\end{array}$ & Mean & $\begin{array}{l}\text { Standard } \\
\text { deviation }\end{array}$ & & \\
\hline $\begin{array}{l}\text { mathematical } \\
\text { communication }\end{array}$ & 7.20 & 1.06 & 7.47 & 1.14 & 0.89 & .000 \\
\hline
\end{tabular}

Table (5) shows that there is a statistically significant correlation at the 0.05 level between the First and second administration scores of cognitive 
achievement and mathematical communication variables. This, however, indicates the reliability of the test. After confirming the validity and reliability of the scale, it was put in its final form as follows:

Table 6.

\begin{tabular}{|c|c|c|}
\hline Order & Dimension & No. of items \\
\hline 1 & The skill of simulation of mathematical relationships in \\
different ways & 2 \\
\hline 2 & The skill of mathematical expressions transfer in a coherently & 3 \\
\hline 3 & The skill of analyzing and evaluating mathematical discussions & 2 \\
\hline 4 & The skill of using mathematical language & 3 \\
\hline
\end{tabular}

So, the scale is ready for the administration.

\section{Teacher's Guide}

To ascertain the validity and appropriateness of the teacher's guide content, it was distributed to six faculties at the University of Hail. It was distributed as follows: Four of them hold doctoral degrees in methods of teaching mathematics and science, while two of hold doctorate degrees in educational psychology. Also, they made some minor modifications based on their observations. For the test, the criteria for accepting test items were $80 \%$. Thus, some items were deleted and modified which got less than that percentage.

The preparation of the teacher's guide passed through the following stages.

1- $\quad$ Teacher's guide for teaching the unit using Ausubel's model.

2- $\quad$ Teacher's guide for teaching the unit using (K.W.L) strategy.

\section{Procedures for Preparing the Teacher's Guide}

1. The researcher prepared and designed the lessons and put them in the teacher's guide for the two views which is based on Ausubel's model and (K.W.L) strategy. The researcher trained the teachers involved in the implementation of the study through workshops to clarify the strategy and implementation steps in mathematics classes.

2. The researcher guided the teachers to teach to Ausubel's model to the first experimental group and (K.W.L) strategy for the second experimental group.

3. The researcher guided the teachers to conventionally teach the control group according to the teacher's guide of mathematics for second stage - middle school students. 


\section{Validity}

\section{Extreme-groups Validity}

Extreme-groups comparison validity was calculated on a sample of 30 students from the research population and from outside the original sample. The difference between upper quartile (8) students and lower quartile (8) students is shown according to following table.

Table 7. The significance differences between upper quartile and lower quartile for the variables of cognitive achievement and mathematical communication

\begin{tabular}{|c|c|c|c|c|c|c|}
\hline Variables & \multicolumn{2}{|c|}{ Lower quartile } & \multicolumn{2}{|c|}{ Upper quartile } & $\mathrm{t}$ & $\begin{array}{c}\text { Significanc } \\
\mathrm{e}\end{array}$ \\
\hline Cognitive achievement & $\begin{array}{c}9.375 \\
0\end{array}$ & .91613 & $\begin{array}{c}12.375 \\
0\end{array}$ & $\begin{array}{c}.5175 \\
5\end{array}$ & $\begin{array}{c}8.06 \\
4\end{array}$ & .000 \\
\hline $\begin{array}{c}\text { Mathematical } \\
\text { communication }\end{array}$ & $\begin{array}{c}6.250 \\
0\end{array}$ & $\begin{array}{c}1.1649 \\
6\end{array}$ & 8.6250 & $\begin{array}{c}.5175 \\
5\end{array}$ & $\begin{array}{c}5.27 \\
0\end{array}$ & .000 \\
\hline
\end{tabular}

Table 7 shows that there are statistically significant differences at the 0.05 level between the upper quartile and the lower quartile in favor of upper quartile in cognitive achievement and mathematical communication. This, however, means that the test has the ability to distinguish between high-level groups and low-level groups indicating the test validity.

\section{Reliability}

Test reliability was confirmed by administering the test to a sample of 30 students from the research community and from outside the original sample. Then, it repeated the administration on the same participants after 10 days in the same circumstances. The following table illustrates this:

Table 8. Correlation between first and second administration of cognitive achievement and mathematical communication test

\begin{tabular}{|c|c|c|c|c|c|c|}
\hline \multirow[b]{2}{*}{ Variables } & \multicolumn{2}{|c|}{$\begin{array}{c}\text { First } \\
\text { administration }\end{array}$} & \multicolumn{2}{|c|}{$\begin{array}{c}\text { Second } \\
\text { administration } \\
\end{array}$} & \multirow[b]{2}{*}{$\mathrm{t}$} & \multirow[b]{2}{*}{$\begin{array}{c}\text { Significan } \\
\text { ce }\end{array}$} \\
\hline & Mean & $\begin{array}{c}\text { Standar } \\
\mathrm{d} \\
\text { deviatio } \\
\mathrm{n} \\
\end{array}$ & Mean & $\begin{array}{c}\text { Standar } \\
\mathrm{d} \\
\text { deviatio } \\
\mathrm{n} \\
\end{array}$ & & \\
\hline Cognitive achievement & 10.90 & 1.27 & 11.20 & 1.32 & $\begin{array}{c}0.8 \\
7\end{array}$ & .000 \\
\hline $\begin{array}{l}\text { Mathematical } \\
\text { communication }\end{array}$ & 7.20 & 1.06 & 7.47 & 1.14 & $\begin{array}{c}0.8 \\
9 \\
\end{array}$ & .000 \\
\hline
\end{tabular}

Table 8 shows that there is a statistically significant correlation at the 0.05 level between the first and second administration scores of cognitive achievement and mathematical communication. This, however, indicates the reliability of the tests. After confirming the validity and reliability of the scale, it was put in its final form as follows: 


\section{The Pre-administration of the Tools}

All the tools were pre-administered (cognitive achievement and mathematical communication) on all the participants. The following table shows the results of the pre- administration.

Table 9. Analysis of variance for the first, second, and experimental group students' scores and the control group students in the pre- administration of study tools (cognitive achievement and mathematical communication)

\begin{tabular}{|c|c|c|c|c|c|c|}
\hline Variables & $\begin{array}{l}\text { Source of } \\
\text { variance }\end{array}$ & $\begin{array}{c}\text { Freedo } \\
\mathrm{m} \\
\text { degree }\end{array}$ & $\begin{array}{c}\text { Sum } \\
\text { of Squa } \\
\text { re }\end{array}$ & $\begin{array}{l}\text { Squa } \\
\text { re } \\
\text { mean }\end{array}$ & $\mathrm{F}$ & $\begin{array}{l}\text { Significan } \\
\text { ce }\end{array}$ \\
\hline \multirow{2}{*}{ Cognitive achievement } & $\begin{array}{l}\text { Between } \\
\text { groups }\end{array}$ & 2.583 & 2 & 1.292 & \multirow{2}{*}{$\begin{array}{c}2.13 \\
8\end{array}$} & \multirow[t]{2}{*}{.121} \\
\hline & $\begin{array}{l}\text { Within grou } \\
\text { ps }\end{array}$ & 99.696 & 165 & .604 & & \\
\hline \multirow{2}{*}{$\begin{array}{l}\text { Mathematical } \\
\text { communication }\end{array}$} & $\begin{array}{l}\text { Between } \\
\text { groups }\end{array}$ & .155 & 2 & .077 & \multirow[t]{2}{*}{.131} & \multirow[t]{2}{*}{.878} \\
\hline & $\begin{array}{l}\text { Within grou } \\
\text { ps }\end{array}$ & 97.750 & 165 & .592 & & \\
\hline
\end{tabular}

Table 7 shows that there are no statistically significant differences between the responses of the groups indicating the homogeneity and matching among the three groups

\section{Results}

The study aimed to investigate the effect the Ausubel's model and (K.W.L) strategy in the teaching statistics and probability unit. This is based on achievement and mathematical communication for second grade middle school students at three middle schools in Hail city. The results were as follows:

\section{The First Hypothesis}

"There is no significant difference at the 0.05 level between the mean score of the experimental group students and those of control one in cognitive achievement due to teaching strategy."

To test this hypothesis, the researchers used one-way variance analysis for the achievement scores according to varied teaching methods. This is as shown in table 10 .

Table 10. One-way variance analysis for the achievement scores according to varied teaching methods

\begin{tabular}{|c|c|c|c|c|c|c|}
\hline & $\begin{array}{c}\text { Source of } \\
\text { variance }\end{array}$ & $\begin{array}{c}\text { Freedo } \\
\mathrm{m} \\
\text { degree }\end{array}$ & $\begin{array}{c}\text { Sum } \\
\text { of Squar } \\
\mathrm{e}\end{array}$ & $\begin{array}{c}\text { Squar } \\
\mathrm{e} \\
\text { mean }\end{array}$ & $\mathrm{F}$ & $\begin{array}{c}\text { Significan } \\
\text { ce }\end{array}$ \\
\hline \multirow{2}{*}{$\begin{array}{c}\text { Cognitive } \\
\text { achievement }\end{array}$} & $\begin{array}{c}\text { Between } \\
\text { groups }\end{array}$ & 2 & 924.08 & $\begin{array}{c}462.0 \\
4\end{array}$ & $\begin{array}{c}.00 \\
0\end{array}$ & 492.59 \\
\cline { 2 - 7 } & Within groups & 165 & 154.77 & .938 & \\
\hline
\end{tabular}


Table 10 shows that there are significant differences at the 0.05 level in the mean score of cognitive achievement due to the different methods of teaching. Scheffe's test was used to determine to which group the differences is in favor of.

Table 11. Significance of differences using scheffe's test among the three groups for cognitive achievement scores

\begin{tabular}{|c|c|c|c|c|}
\hline Group & means & means & means & المجموعات \\
\hline Control & 6.32 & & $4.89 *$ & $5.05^{*}$ \\
\hline Experimental 1 & 11.21 & $4.89 *$ & & 0.161 \\
\hline Experimental 2 & 11.38 & $5.05^{*}$ & 0.161 & \\
\hline
\end{tabular}

$*$ Significant at the $(0.01)$ level $* *$ Significant at the $(0.01)$ level

Table 11 shows that there are significant differences due to the different method of teaching which is in favor of the experimental group differences (1) compared to the control group, and the means score of the students who studied using Ausubel's model is higher than students who studied in the conventional method. Also, there are significant differences in favor of the experimental group (2) compared to the control group, and the means score of the students who studied using (KWL) strategy is higher than students who studied using the conventional method. The differences are not significant between the experimental group (1) and the experimental group (2). Thus, it can be said that the two strategies (Ausubel's model and (K.W.L) strategy) are more effective in improving achievement in mathematics compared to the conventional method.

\section{The second hypothesis}

"There is no significant difference at the 0.05 level between the mean score of the experimental group students and those of the control one in mathematical communication due to teaching strategy."

To test this hypothesis, the researchers used one-way variance analysis for the mathematical communication scores according to varied teaching methods. This is as shown in table 12 below.

Table 12. One-way variance analysis for the mathematical communication scores according to varied teaching methods

\begin{tabular}{|c|c|c|c|c|c|c|}
\hline \multirow{2}{*}{ Variable } & $\begin{array}{c}\text { Source of } \\
\text { variance }\end{array}$ & $\begin{array}{c}\text { Freedo } \\
\mathrm{m} \\
\text { degree }\end{array}$ & $\begin{array}{c}\text { Sum } \\
\text { of Squa } \\
\text { re }\end{array}$ & $\begin{array}{c}\text { Squa } \\
\text { re } \\
\text { mean }\end{array}$ & F & $\begin{array}{c}\text { Significa } \\
\text { nce }\end{array}$ \\
\hline \multirow{2}{*}{$\begin{array}{c}\text { Mathematical } \\
\text { Communication }\end{array}$} & $\begin{array}{c}\text { Between } \\
\text { groups }\end{array}$ & 2 & 394.48 & $\begin{array}{c}197 . \\
24\end{array}$ & $\begin{array}{c}387 . \\
43\end{array}$ & .000 \\
\cline { 2 - 6 } & $\begin{array}{c}\text { Within grou } \\
\text { ps }\end{array}$ & 165 & 84 & .509 & & \\
\hline
\end{tabular}


Table 12 shows that there are significant differences at the 0.05 level in the mean score of mathematical communication due to the different methods of teaching. Scheffe's test was used to determine which group the differences are in favor of, as follows:

Table 13. Significance of differences using scheffe's test among the three groups for mathematical communication scores

\begin{tabular}{|c|c|c|c|c|}
\hline Group & Means & Means & Means & Groups \\
\hline Control & 4.14 & & $2.79 *$ & $3.57^{*}$ \\
\hline Experimental 1 & 6.93 & $2.79^{*}$ & & $0.786^{*}$ \\
\hline Experimental 2 & 7.71 & $3.57^{*}$ & $0.786^{*}$ & \\
\hline
\end{tabular}

$*$ Significant at the $(0.01)$ level $* *$ Significant at the $(0.01)$ level

Table 13 shows that there are significant differences due to the different method of teaching in favor of the experimental group differences (1) compared to the control group, and the means score of the students who studied using Ausubel's model is higher than students who studied in the conventional method. Also, there are significant differences in favor of the experimental group (2) compared to the control group, and the means score of the students who studied using (KWL) strategy is higher than students who studied in the conventional method. The differences are significant between the experimental group (1) and the experimental group (2) in favor of the experimental group (2). Thus, it can be said that the (K.W.L) strategy is more effective in improving mathematical communication in mathematics compared to Ausubel's model and the conventional method.

\section{The third hypothesis}

"There is no significant difference at the 0.05 level among the mean score of experimental groups students and those of the control one (achievement and mathematical communication) due to teaching strategy."

To test this hypothesis, the $t$-test for dependent means was used to compare the mean scores of experimental groups' students and those of the control one (pre and post administration) for achievement and mathematical communication, due to teaching strategy, as shown in Table 14 below.

Table 14. $t$-test for dependent means for mean scores of experimental groups and the control one (pre and post administration) for achievement and mathematical communication, according to teaching strategy

\begin{tabular}{|c|c|c|c|c|c|c|c|}
\hline Groups & \multicolumn{2}{|c|}{$\begin{array}{c}\text { Mean score of pre- } \\
\text { administration }\end{array}$} & $\begin{array}{c}\text { Mean score of } \\
\text { post- } \\
\text { administration }\end{array}$ & $\begin{array}{c}\text { Diffe } \\
\text { rence } \\
\text { mean }\end{array}$ & $\begin{array}{c}\text { Sd } \\
\text { for } \\
\text { differ } \\
\text { ences }\end{array}$ & $\mathrm{t}$ & $\begin{array}{c}\text { Signifi } \\
\text { cance }\end{array}$ \\
\hline $\begin{array}{c}\text { Control } \\
\text { group }\end{array}$ & $\begin{array}{c}\text { achieveme } \\
\text { nt }\end{array}$ & $\begin{array}{c}2.571 \\
4\end{array}$ & 6.3214 & 3.75 & 1.16 & $\begin{array}{c}24 . \\
11\end{array}$ & .000 \\
\hline
\end{tabular}




\begin{tabular}{|c|c|c|c|c|c|c|c|}
\hline & $\begin{array}{l}\text { Mathemati } \\
\text { cal } \\
\text { communic } \\
\text { ation }\end{array}$ & $\begin{array}{c}1.482 \\
1\end{array}$ & 4.1429 & 2.66 & 1.12 & $\begin{array}{l}17 . \\
83\end{array}$ & .000 \\
\hline \multirow[b]{2}{*}{$\begin{array}{c}\text { Experimenta } \\
1 \text { group (1) }\end{array}$} & $\begin{array}{c}\text { achieveme } \\
\text { nt }\end{array}$ & $\begin{array}{c}2.285 \\
7\end{array}$ & 11.2143 & 8.93 & 1.35 & $\begin{array}{l}49 . \\
62\end{array}$ & .000 \\
\hline & $\begin{array}{l}\text { Mathemati } \\
\text { cal } \\
\text { communic } \\
\text { ation }\end{array}$ & $\begin{array}{c}1.553 \\
6\end{array}$ & 6.9286 & 5.38 & 1.09 & $\begin{array}{l}36 . \\
96\end{array}$ & .000 \\
\hline \multirow[b]{2}{*}{$\begin{array}{l}\text { Experimenta } \\
1 \text { group (2) }\end{array}$} & $\begin{array}{c}\text { achieveme } \\
\text { nt }\end{array}$ & $\begin{array}{c}2.339 \\
3\end{array}$ & 11.3750 & 9.04 & 1.35 & $\begin{array}{l}50 . \\
16\end{array}$ & .000 \\
\hline & $\begin{array}{l}\text { Mathemati } \\
\text { cal } \\
\text { communic } \\
\text { ation }\end{array}$ & $\begin{array}{c}1.535 \\
7\end{array}$ & 7.7143 & 6.18 & 1.03 & $\begin{array}{l}44 . \\
94\end{array}$ & .000 \\
\hline
\end{tabular}

Table 14 shows that there is significant difference at the 0.05 level among the mean score of the experimental group students and those of the control one in achievement and mathematical communication in favor of the post administration.

\section{Discussion of Results}

In the light of the previous results, there is significant difference at the 0.05 level among the mean score of experimental group students and those of the control ones. This is due to teaching strategy in favor of the experimental group (1) and experimental group (2). Thus, Ausubel's model and (K.W.L) strategy are more effective in improving cognitive achievement in mathematics in comparison to the conventional method. However, this can be interpreted as follows:

- Teaching using methods helps in organizing information, forming relationships, connecting between information in the cognitive structure, and providing students with knowledge that can be transferred to be a later part of the intellectual ability and the tally of knowledge. This would have the organizational strength and a capacity to help them in the new perception of information.

- Teaching using methods facilitated to increase the clarity of the meaning of the topics presented, and thus the content taught to a student, can offer a great sense. A student can easily remember meaningful information, on contrary. Otherwise, if information is meaningless to a student, it will be forgotten easily.

- Both methods aimed to form these new meanings in knowledge structure. It influenced learners' responses, helped to increase the degree of stability and clarity of the new meanings, and raise the degree of learning 
effectiveness, thereby increasing the mathematical achievement. This result is consistent with the results of other studies (Abdali, 2006; Tok, 2008; Siribunnam- Tayraukham, 2009; Al-Zubaidi, 2011; Al-Khathlan, 2012; \& Aram, 2012).

As for mathematical communication, there are significant differences because the different method of teaching is in favor of the experimental group differences (1) compared to the control group, and the means score of the students who studied using Ausubel's model is higher than students who studied in the conventional method. Also, there are significant differences in favor of the experimental group (2) compared to the control group, and the means score of the students who studied using (KWL) strategy is higher than students who studied in the conventional method. The differences are significant between the experimental group (1) and the experimental group (2) in favor of the experimental group (2). However, (K.W.L) strategy is more effective in improving mathematical communication in mathematics compared to Ausubel's model and the conventional method. This can be attributed to:

- Teaching by using the two methods which gave many and frequent opportunities to communicate orally and in written form (via the many lessons of the course). This helps students to deepen their understanding of the concepts of mathematical ideas through writing and talking about these mathematical concepts in their own words. It has also helped student by listening to what their colleagues are saying about these ideas and then gave so entrenched mathematical concepts ideas. Therefore, this highlighted the level of understanding of the two students in the experimental groups compared to their peers in the control group that was not exposed to such communicative tasks. Furthermore, this valuable communication, as indicated in many of the previous studies and literature, is directly and positively affecting the mathematical communication.

Consequently, the superiority of the second experimental group and what it causes in strengthening the confidence in students as they learn and express the extent of their knowledge and understanding was clearly shown. This is the result of nature reflected in the mathematical communication which was confirmed by other studies (Metwally, 2006; Al-Nazeer \& Khashan, 2012; \& Barakati, 2008).

\section{Recommendations}

In light of the results that have been reached, the researcher concluded on a set of recommendations:

- $\quad$ Teachers should benefit from the methods used and their impact on the effective teaching of mathematics at the university level for the development of mathematical communication skills. 
- The attention of mathematics teachers should be driven at the university level to employ mathematical tasks in the development of mathematical communication skills.

- There is the need to provide opportunities for university students to use their ideas in verbal expressions and non-verbal communication during the study of mathematics. They should not overlook this aspect under the pretext of pressure, intensity of courses, and limited time.

In addition, they should focus on advanced organizations in the stages of warming up in lessons.

- $\quad$ Paying attention to the clarity of learning materials in order to consolidate in mind, as meaningful, to make it easier to remember, and using them in different life situations.

- $\quad$ Adopting the principle of maintaining learning materials as a key criterion in evaluating form of the performance of teachers by specialist educators.

- $\quad$ Adopting the issue of linking education to learner's environment through building on background knowledge in addressing the new teaching materials in the classroom.

\section{Suggestions}

- $\quad$ Conducting a study on the impact of the use of modern teaching strategies in achievement, mathematical thinking, and mathematical communication.

- The effect of using the two views of (K.W.L) strategy and Ausubel's model electronically in the teaching of mathematics for the first-grade middle school students' achievement and mathematical communication.

- $\quad$ Conducting further research and studies on the impact of the use of the training programs based on modern strategies in teaching and mathematical communication in mathematics education and in the various stages of education.

\section{References:}

1. Abdali Mohammed Saleh (2006). The effect of using the educational models of Gagne and Ausubel on achievement and learning retention in first grade secondary students in biology in the province of Abyan, Unpublished MA, Faculty of Education, University of Aden.

2. Al-Amin Ismail Mohamed (2001). Methods of teaching mathematics: theories and implementation .Series of references in education and psychology, vol. (17), , Cairo: Dar Al-fekr AlAraby. 
3. Al-Nazeer Mohammed \& Khashan Khaled (2012). The impact of a training program based on the criterion of mathematical communication in achievement and attitudes towards mathematics at the preparatory year students at King Saud University, the Arabian Gulf message, (126), pp. 115156.

4. Al-Zahrani, Ghaida (2011). The effect of using K.W.L strategy on academic achievement in English syllabus of the female students in the first grade middle school in Mecca, Unpublished MA, College of Education, Umm Al Qura University.

5. Al-Zubaidi Taleb (2011). Learning Retention in the light of Ausubel's theory, Journal of Arab Research and Studies - Egypt, GS 54.413 to 431 .

6. Anderson, A. \& Little, M. (2004). On the Write Path: Improving Communication in an Elementary Mathematics Classroom. Teaching Children Mathematics, 10 (9), 468-472.

7. Aram Mervat Solomon (2012). The impact of the use of strategy (L.W.K) on the acquisition of concepts and critical thinking skills in science among students of the seventh grade, Unpublished MA, College of Education, the Islamic University of Gaza.

8. Atiya \& Ibrahim Saleh Mohammad (2008). The effectiveness of (KWLA) and (think-pair-Share) strategies in the teaching of mathematical communication on creativity development of the primary school pupils, Journal of the Faculty of Education, Benha University, GS (76), mg ( 18), pp. 50-85.

9. Ausubel Robinson Floyd (1998). School learning New York: Holt Rinehart Winston.

10. Badawi Ramadan Massad (2003). Strategies for learning and evaluating mathematics.first Edition, Dar thought

11. Bahloul Ibrahim et al. (2004). Modern trends in metacognitive strategies in the teaching of reading, Journal of reading and knowledge, the Egyptian society for reading and knowledge. (30)

12. Barakati Nevin (2008). The impact of teaching using multiple intelligences and six hats and K.W.L in achievement and interdependence among third grade middle school students in Mecca, unpublished Ph.D., College of Education, Umm Al Qura University.

13. Bayat, S \& Tarmizi, R. (2010). Assessing cognitive and metacognitive strategies during algebra problem solving among university students. Procedia Social and Behavioral Sciences, Volume 8, Pp. 403-410.

14. Cai, J. \& Jakabcsin, S. (1996). Assessing students' mathematical communication. School Science \& Mathematics, 96 (5), 238-246. 
15. Cook, D. and Buchholz, D. (2005). Mathematical Communication in the Classroom: A Teacher Makes a Difference. Early Childhood Education Journal, 32 (6), 365-369.

16. Ibrahim Magdi Aziz (2005). Teaching creative thinking and learning.The first edition, Alam-Al-Kotob, Cairo.

17. Jennifer Conner (2006). Instructional reading strategy: K.W.L (know, want to know, learned) URL: http://www.indiana.edu/ 1517/KWL.htm

18. Junkie Qasim (2004). Mathematical communication and representation in the basic school students in Jordan in light of the NCTM standards for the year 2000.Unpublished PhD thesis, Jordan, Amman Arab University for Graduate Studies.

19. Kelada Fouad (2008). Strategies and Methods of teaching and instructional models, Part I, 3rd, Tanta: Dar Al Maera Al Gamia

20. Khathlan, Mansour (2012). The effectiveness of a developed computer curriculum at secondary schools in Saudi Arabia, according to a Ausubel and Brunner's Model on students' performance and attitudes toward it, unpublished Ph.D., Institute of Educational Studies and Research, Cairo University.

21. Macdragh , M. K (2001). The Effect of Background Experience and an on the Attainment of Certain Science Concepts. Dissertation Abstract International .Vol. 42 No.2 August, p.612 A.

22. Metwally Aladdin (2006). The effectiveness of using indirect proofing approaches in developing mathematical proof sills and reducing proof anxiety and improving communication skills for mathematics teacher." Journal of Mathematics Educations, Egyptian Association for Mathematics Educations, College of Education, Benha University.

23. National Council of Teachers of Mathematics (NCTM) (2000). Principles and Standards for Mathematics. Reston, Virginia.

24. National Council of Teachers of Mathematics (1989). Curriculum and Evaluation Standards for School Mathematics. Reston,Va: NCTM.

25. Orabi Mohammed (2004). The effective alternative assessment on achievement and communication and reduction of the anxiety of the primary school students," the fourth scientific conference of the Egyptian Society for Mathematics Educations: Mathematics of public education in the knowledge society.

26. Salama Adel Obu-alezz (2002). Methods of teaching science and their role in the development of thinking, Amman: Dar thought. 
27. Siribunnam, R. \& Tayraukham, S. (2009). Effects of 7-E, K.W.L and traditional Instruction on Analytical Thinking, Learning Achievement and Attitudes toward Chemistry Learning, Journal of Social Science, Volume4 , fifth issue, October, P279- 282

28. To'eima Rushdi Ahmed, Abdul Halim Ahmad Mahdi, Al Gamel Mahmoud Kamel, mufti Muhammad Amin, Madkor Ali Ahmed, and Souror Aida Abdul Hamid (2011). Contemporary school curriculum - foundations, design, organizations, and development, p.1 Oman, Dar Al-Masera for publication and distribution.

29. Tok, S. (2008). The Effects of Note Taking and K.W.L Strategy on Attitude and Academic Achievement. Hacettepe University Journal of Education, 34, p244-253. 